Precolonial Institutions and Deforestation in Africa 


\title{
Precolonial Institutions and Deforestation in Africa
}

\begin{abstract}
:
We find that local institutions inherited from the precolonial era continue to play an important role in natural resource governance in Africa. Using satellite image data, we find a significant and robust relationship between deforestation and precolonial succession rules of local leaders (local chiefs). In particular, we find that those precolonial areas where local leaders were appointed by 'social standing' have higher rates of deforestation compared to the base case of hereditary rule and where local leaders were appointed from above (by paramount chiefs). While the transmission mechanisms behind these results are complex, we suggest that areas where local leaders were appointed by social standing are more likely to have poorer institutions governing local leadership and forest management.
\end{abstract}

Keywords: deforestation, Africa, precolonial institutions, chiefs, legal pluralism. 


\section{Introduction}

According to the United Nations Millennium Development Goals Report (2013) close to 75 per cent of the world's forests are now protected by national governments. However, despite the large increase in protected forests in recent decades, deforestation remains a significant problem in much of the developing world. According to the same report, around 3.4 million hectares of net forest were lost per year in Africa for the period 2005 to 2010. The report (2013:42) concludes that "[f]orests are disappearing at a rapid pace, despite the establishment of forest policies and laws supporting sustainable forest management in many countries.'

One reason for continued high rates of deforestation despite a significant increase in state protections is illegal deforestation. Using a model of competitive rent seeking and data from Indonesia, Burgess et al. (2012), provide evidence that a key determinant of deforestation is a lack of enforcement of state protections due to corruption among local politicians and bureaucrats. More recently, Alesina, et. al. (2014) have found that deforestation is correlated with the degree of ethnic fractionalization found within local communities. Conceiving forests as community public goods, they conclude that more ethically fractionalized societies are less able to coordinate and organize resistance against the consequences of poor state institutions, corrupt politicians and illegal logging.

We contribute to this literature that looks beneath the surface of state regulation by investigating the role that precolonial institutions play in relation to deforestation. Despite over 95 per cent of African forests falling under public ownership and approximately 80 per cent being managed by the state (FAO, 2010:10), we hypothesize that the remnants of precolonial institutions continue to play an important role in forest management and rates of deforestation. Specifically, we examine the relationship between the succession rules of village heads (local chiefs) and current rates of deforestation in Africa. We undertake this analysis using deforestation data obtained from satellite images within 645 boundaries of precolonial societies and within the boundaries of 49 states in Africa. In doing so, we control for known and likely drivers of deforestation; including protected areas, population density, a range of geographic characteristics (including elevation and vegetation regions), economic variables (including light density at night), institutional variables (including rule of law and form of colonial rule), and country fixed effects. 
This paper is motivated by a growing literature that highlights the enduring importance of precolonial institutions on a range of current outcomes in Africa: Gennaioli and Rainer (2007), Ziltener and Mueller (2007), Fenske (2013, 2014), Larcom (2013), and Michalopoulos and Papaioannou $(2013,2014)$, and have all found a strong statistical relationship between measures of precolonial institutions and current measures of institutional quality. While there are different explanations put forward for these results, they all are grounded on the premise that states are relatively weak across much of Africa, especially in rural areas, and that this creates demand for non-state regulation. On this, Michalopoulos and Papaioannou (2013:115) conclude that the 'inability of African states to provide public goods and broadcast power beyond the capitals led African citizens to continue relying on the local ethnic-specific structures rather than the national Government'. Acemoglu et al. (2014:362) reach a similar conclusion regarding the capacity of the state in Africa, finding that the 'majority of the population lives in rural areas and where the national state often lacks capacity and the power to "penetrate" society".

While precolonial institutions may persist in many parts of Africa, it is another matter linking them to natural resource management, and deforestation in particular. However, there are good reasons to do so. In a comparative study of land tenure systems across the continent, Otsuka and Place (2001) conclude that primary forests and uncultivated woodlands are still largely governed by communal ownership regimes with control rights vested with local chiefs or other traditional local authorities. They also conclude that the continuation of these types of governance regimes differs from much of Africa's farm land, where individual ownership rights are much more common. Ensminger (1997) also concluded that communal ownership of forest resources spans across much of Africa. The link between resource management and traditional institutions is also supported by recent large-scale survey data from AFRObarometer that confirms the continued importance of indigenous institutions in rural Africa, especially in relation to dispute resolution and use of land (Logan 2013). ${ }^{1}$

In an investigation of deforestation in the South Nandi and Karura Forests of Kenya, Klopp (2012) found that forests are often incorporated into the patronage networks of elites and resources are distributed in return for political support. Brown and Makana (2014:3) also found

\footnotetext{
${ }^{1}$ See also Thondhlana et al. (2015) and Osei-Tutu et al. (2014) who document traditional local institutions and local leaders continuing to play a role in natural resource governance in contemporary Africa (along with state and othernon state institutions).
} 
that much of the deforestation in the northeast of the Democratic Republic of Congo was generated by small-scale loggers who paid 'traditional chiefs' for logging permits. However, they found that the permits often had no legal status from the national government and that the funds received were appropriated by the chiefs themselves with little benefit to the local community. They also found that some loggers who wished to secure access to forests for logging provided local chiefs with gifts, such as motorcycles. It is suggested here that the different institutional structures that govern natural resources should be related to the rate of deforestation due to the importance of institutional checks and balances on the performance of local leaders. Acemoglu et al. (2014) have recently found that chiefs with fewer checks and balances on their power produce worse economic development outcomes for their people, primarily through their ability to engage in self-interested behaviour that is made possible through their control of land and natural resources.

In terms of village chiefs, institutional checks and balances can come from above (e.g. paramount chiefs) or from below (e.g. democratic accountability). We can expect that the checks and balances on those who are vested with control rights over land and natural resources will directly influence the rate of deforestation. Where less checks and balances are in place, the pursuit of self-interested forest management practices is more possible and this can lead to increased logging and deforestation. Conversely, where local leadership is checked, we could expect the remnants of precolonial institutions to guard against corrupt officials and predatory logging companies. In addition, different sources of local authority may generate more conflict and uncertainty over the use rights of natural resources than others. For instance, Filer (2012) and Larcom (2015) have documented how highly dispersed local customary institutions in Papua New Guinea can lead to both internal and external conflict over forest resources. This conflict can lead to uncertainty over ownership that can devalue the natural resource and encourage those who have access to it to exploit it faster than they otherwise would like. Different sources of local authority may also lead to variations in the costs associated with co-ordination against outsiders wishing to exploit their resources and therefore lead to different levels of deforestation. 


\section{Materials and Methods}

Our empirical method focuses on estimating the relationship between the succession rules for village heads with deforestation data from 2000-2012 obtained from satellite data within 645 boundaries of precolonial societies and within the boundaries of 49 states in Africa. Due to the potential for omitted variable bias we control for all known and likely drivers of deforestation (see Barbier and Burgess (2001), Burgess et al. (2012), Geist and Lambin 2002 and DeFries et al. 2010) including, protected areas, population density, a range of geographic characteristics (including elevation and vegetation regions), economic variables (including light density at night), institutional variables (including rule of law and form of colonial rule) and country fixed effects.

Specifically, we estimate the relationship between local precolonial institutions and recent rates of deforestation by estimating variants of the following model:

$$
d_{i, c}=\alpha_{0}+\beta P_{i}+X_{i, c}^{\prime} \Phi+c_{c}+\varepsilon_{i, c}
$$

where, $d_{i, c}$ is the rate of forest change for the period 2000-2012 in each precolonial society $i$ in country c. $P_{i}$ represents our precolonial institutional measures, $X_{i, c}$ is a vector of control variables that consist of the broad headings of current institutions, colonial institutions, population density, geographical, economic development and forest stock controls, and $c_{c}$ are country fixed effects. To account for the possibility of spatial correlation we use double clustered standard errors at the ethnic-family level and country level (Cameron et al. 2011, Michalopoulos and Papaioannou 2013, 2014). Where possible, we include country fixed effects to account for time invariant differences that are country specific.

While we acknowledge the potential for endogeneity inherent in the use of institutions as predictors, we consider that this is mitigated by the fact that our measures are indeed precolonial and that we control for a wide variety of (largely immutable) geographic characteristics. Finally, while there have been large migrations and forced displacements within Africa, Nunn and Wantchekon (2011) have found a strong correlation (0.55) between the current location of residents and their historical ethnic homelands as identified by Murdock (1967). Due to the unavailability of data we do not explicitly include a measure for ethnic fractionalization at the 
precolonial level, however we do include a number of geographic variables that are known drivers of ethnic fractionalisation (see Michalopoulos 2012) and use country fixed effects that should capture any variance in ethnic fractionalization at the country level.

Data

\subsubsection{Spatial data on deforestation}

The main measure of deforestation is sourced from Hansen et al. (2013). It represents the percentage of net forest loss within the boundaries of each precolonial society from 2000 to 2012; where net forest loss is the difference between loss and gain of forest cover. As can be seen from Table 1, over this period mean deforestation is 1.090 per cent with a standard deviation of 1.491 per cent. The largest amount of deforestation of any area was 15.515 per cent, while the largest net gain was 0.964 per cent. Figure 1 illustrates the degree of deforestation in each precolonial society between 2000 and 2012. Most deforestation occurred within the tropics, predominantly in West Africa and, to a lesser extent, in the Congo basin and the south east of the continent (Mozambique and Tanzania). When focusing on the designated forested regions of Africa only, it can also be seen from Table 1 that deforestation is higher over the sample period; at 1.607 per cent compared to 1.090 per cent for the continent as a whole.

Figure 1: Deforestation within precolonial and national boundaries 


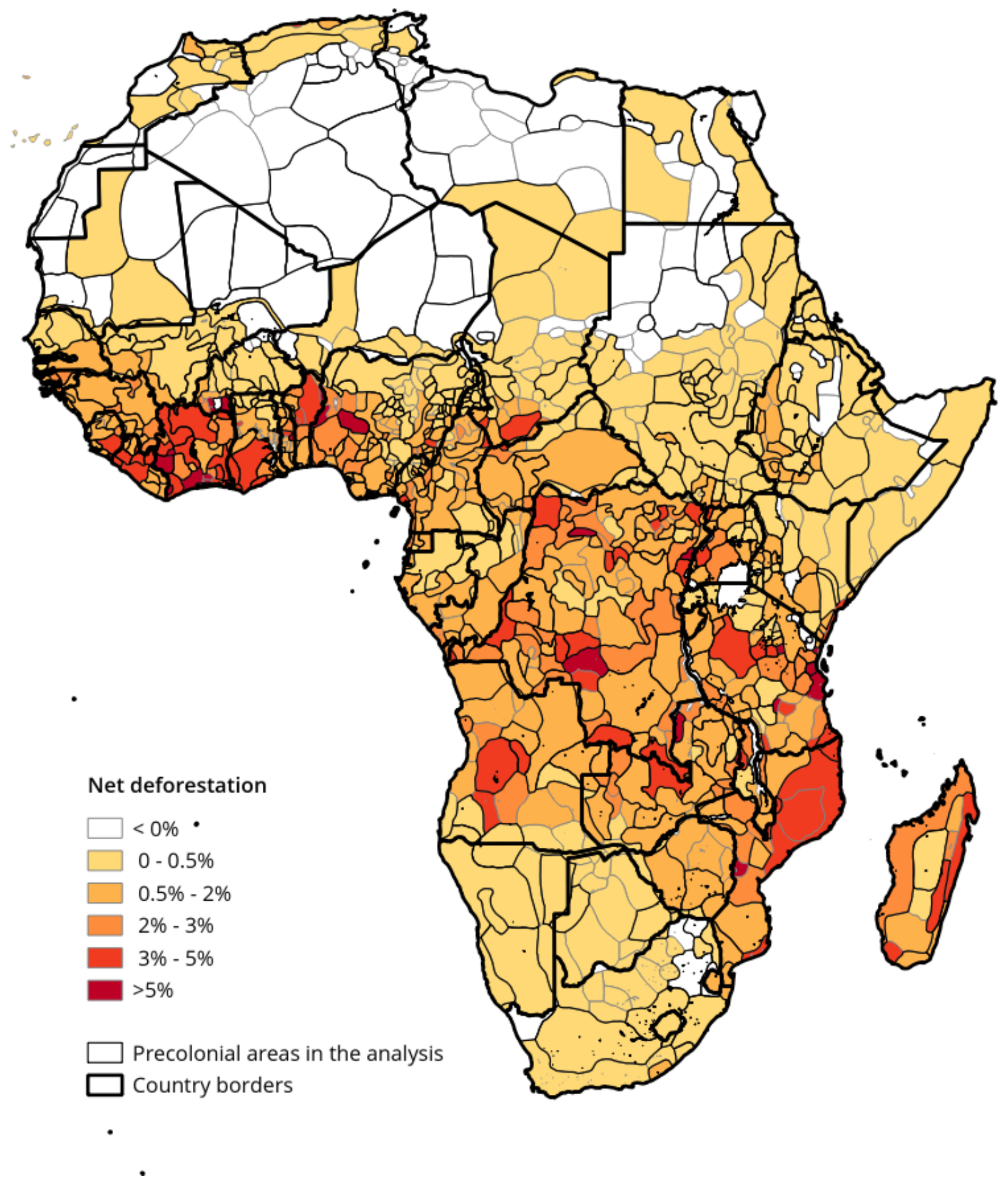

Figure 2: Precolonial boundaries of Africa 


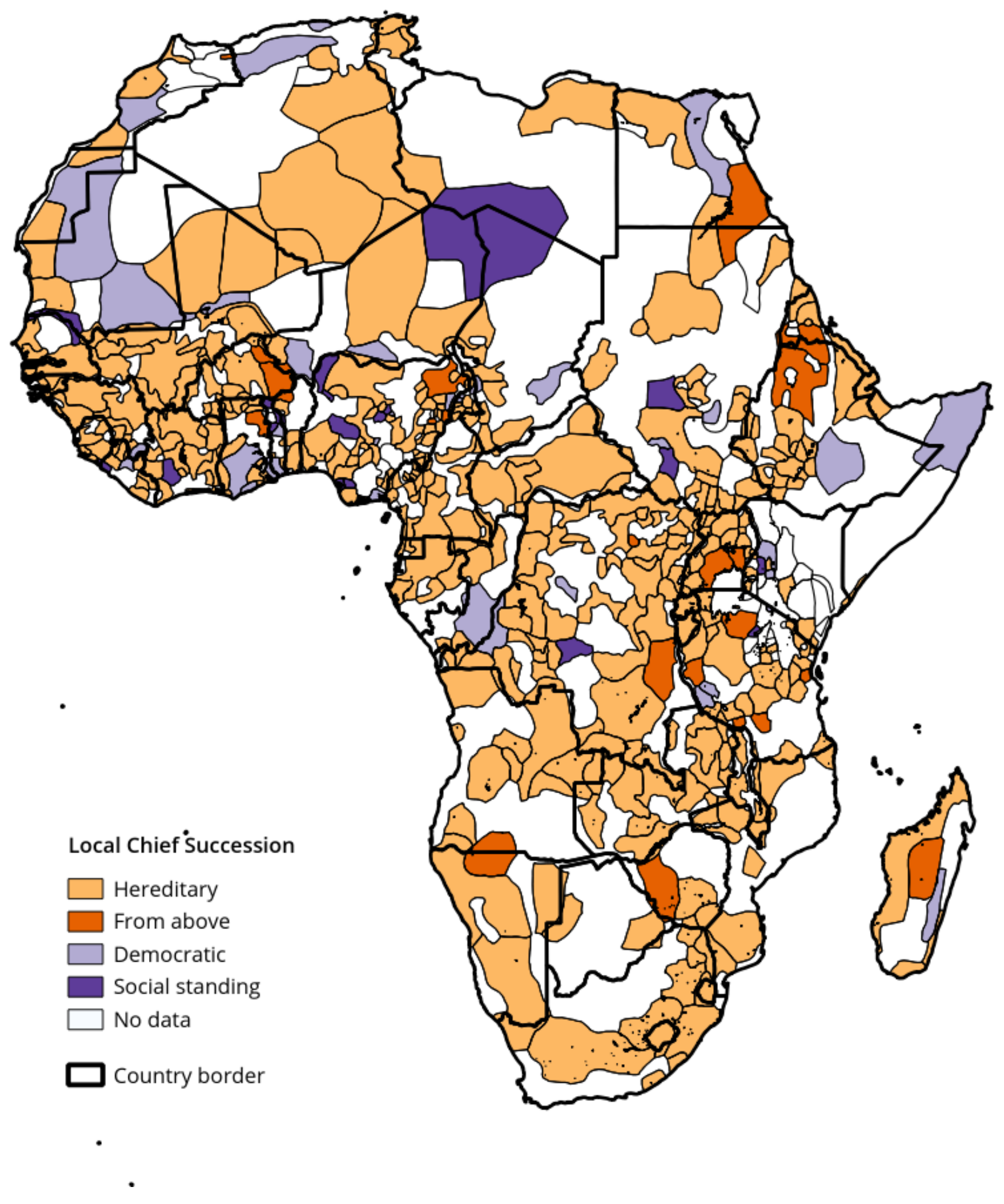

\subsubsection{Precolonial Institutions}

We use quantitative ethnographic data from Murdoch's (1967) Ethnographic Atlas to measure local precolonial institutions under the following succession rules: hereditary appointment, 
democratically appointment, appointed from above, or appointed by social standing. Murdock sourced his data from descriptions from anthropologists during the late $19^{\text {th }}$ Century and first half of the $20^{\text {th }}$ Century. As can be seen from Table 1, the majority of local village heads in Africa were appointed on hereditary grounds, and hereditary succession is therefore used as the base case for our econometric analysis. As can be seen from Figure 2, the geographic distribution of different local village head succession rules does not present clear patterns. While the hereditary rule predominates, democratic rule is found in the Atlantic side of Maghreb, the Horn of Africa, and the lower Nile basin; and 'social standing' and 'from above' appear to have a largely random distribution.

It can also be seen from Figure 2 that precolonial societies vary in size considerably. The mean area of a precolonial society is approximately 26,000 square kilometres (roughly the same size of the island of Sicily); while the smallest is 110 square kilometres and the largest is 494,000 square kilometres (with a standard deviation of 47,000 square kilometres). Given that many societies are spread across different countries, consistent with the methodology of Michalopoulos and Papaioannou (2013), we intersect Murdock's digitised ethnolinguistic map with the 2000 Digital Chart of the World to identify partitioned ethnicities and assign each ethnic area to a specific country. This sees 191 precolonial institutions split into 2 or more countries in our sample. ${ }^{2}$ In terms of precolonial societies per country, the mean is 13.86 (with a standard deviation of 14.27). Nigeria has the highest number of precolonial societies within its borders (with 61), while Swaziland has only 1. In terms of within country variation of succession rules, the mean is 3.06 succession rules per country (with a standard deviation of 0.92 ), with 3 countries recording the minimum of 1 and 19 countries recording the maximum of 4 .

Given that the literature highlights the importance of local leadership for forest management in Africa, we focus our analysis on local precolonial institutions. However, given that political centralization (or jurisdictional hierarchy) has been shown to be an important variable for a number of other studies linking precolonial institutions to current institutional outcomes, we include a measure of political centralization in our estimations; where a value of 0 represents a

\footnotetext{
${ }^{2}$ The mean number of countries that precolonial institutions were split into was 1.549 with a standard deviation of 0.727 , minimum of 1 and maximum of 6 .
} 
politically fragmented society and a value of 1 represents a politically centralized society (see Gennaioli and Rainer 2007).

\subsubsection{Colonial Institutions}

Given the potential role that colonial institutions may play, we use Ziltener and Kunzler's (2013) data on the duration of colonial rule and the form of colonial rule. The form of colonial rule measures different levels of colonial rule: no colonial domination, semi-colonialism, indirect rule with minimal interference in internal affairs, indirect rule with significant interference in internal affairs, and direct rule. As our dataset did not include any states characterized by no colonial domination or semi-colonialism, we only included the two categories of indirect rule and direct rule. Indirect rule is characterized by the colonial power having: claimed exclusive rights over the colonized society's foreign relations, defended (or likely to have defended) the society from third countries, deployed an actor to influence and check the decisions made by the indigenous leader, and held direct control over some administrative structures. Societies classified as having been under direct rule are defined as societies where the traditional political system was replaced with a new political structure (see further details in Table S1 in Appendix).

We also use an intensity of colonization measure that is the sum of the logarithms of the duration of colonial rule and the form of political domination (indirect or direct rule), and a binary measure of legal origin, where 0 represents countries with British legal origins and 1 represents countries with French legal origins (La Porta et al. 2001).

\subsubsection{Current Institutions}

Current institutions are measured by the rule of law and protected areas. We use the World Bank's rule of law index, which aims to measure the quality of state institutions, 'in particular the quality of contract enforcement, property rights, the police, and the courts, as well as the likelihood of crime and violence' (Kaufmann et al. 2008). The index is normalized and runs from -2.5 to 2.5 with higher values indicating better rule of law. In our sample, we find a mean value of -0.861 with a standard deviation of 0.553 and a minimum of -1.912 . Protected areas refers to the percentage of area within a precolonial society that is protected and which was declared as such on or before 2003. Our operational definition of protected areas is broad and includes protected forests governed both by the state and non-state actors. To construct our 
measure of protected forests we used the Protected Planet dataset (IUCN and UNEP-WCMC, 2013). The dataset includes all areas with designated protection and this includes the range of IUCN protection categories (I to VI), as well as areas outside of the IUCN scale. This global database is the most complete to date. However, due to visibly inaccurate spatial data, we eliminated UNESCO Biosphere Reserves and replaced Ramsar areas with official data (Ramsar 2013). We also excluded protected areas labelled as marine reserves and whose status was 'proposed' or 'not reported'. In order to merge overlapping protected areas we dissolved all areas into a single multi-part polygon. The resulting data layer thus classifies the continent into protected and not-protected. We then calculated the percentage of area protected within each precolonial society. In our sample, the mean ratio of protected area to the total land area was 12.333 per cent with a standard deviation of 18.304 per cent.

Table 1: Summary statistics

\begin{tabular}{lrrrrrr}
\hline \multicolumn{1}{c}{ Variable } & \multicolumn{1}{c}{$\begin{array}{c}\boldsymbol{N}= \\
\mathbf{1}\end{array}$} & Mean & $\begin{array}{c}\text { Std. } \\
\text { Dev. }\end{array}$ & Min & Max \\
\hline Deforestation & 683 & - & 1.090 & 1.491 & -0.964 & 15.515 \\
Deforestation (forests only) & 282 & - & 1.607 & 1.522 & -0.421 & 8.087 \\
Deforestation (alternative measure) & 683 & - & 1.694 & 23.698 & -71.606 & 75.105 \\
Deforestation (alternative measure, forests & 281 & - & 7.034 & 23.796 & -71.606 & 74.378 \\
only) & & & & & & \\
Rule of law & 683 & - & -0.861 & 0.553 & -1.912 & 0.708 \\
Protected areas & 683 & - & 12.333 & 18.304 & 0 & 100 \\
Colonial duration & 668 & - & 110.967 & 79.878 & 15 & 469 \\
Indirect rule & 668 & 457 & 0.684 & 0.465 & 0 & 1 \\
Colonial intensity & 668 & - & 5.015 & 0.697 & 2.708 & 6.700 \\
Legal origins & 680 & 376 & 0.553 & 0.498 & 0 & 1 \\
Political centralization & 683 & 243 & 0.356 & 0.479 & 0 & 1 \\
Chief succession (hereditary) & 645 & 531 & 0.823 & 0.382 & 0 & 1 \\
Chief succession (democratic) & 645 & 50 & 0.078 & 0.268 & 0 & 1 \\
Chief succession (from above) & 645 & 38 & 0.059 & 0.236 & 0 & 1 \\
Chief succession (social standing) & 645 & 26 & 0.040 & 0.197 & 0 & 1 \\
\hline
\end{tabular}




\subsubsection{Control variables}

We compiled a number of control variables that are known or likely to be related to deforestation (see details Table S1 in Appendix). ${ }^{3}$ We grouped these controls into four categories: population density, geographic controls (including elevation, longitude and latitude), economic development controls (light density) and forest stock controls. Summary statistics for our control variables can be found in the Appendix (Table S4). The data on vegetation is based on terrestrial ecoregions of the world from WWF (Olson et al. 2001; see Figure 3). We grouped the 126 categories of ecoregions from this database that are present in Africa in nine major categories: forest, woodland, grassland, desert, mangrove, savannah, bushland (which includes thicket, moorland, scrubland), miombo, and other low vegetation or unique ecosystems (which includes fynbos, Karoo, steppe, halophytic). ${ }^{4}$

\section{Figure 3: Vegetation zones of Africa}

\footnotetext{
${ }^{3}$ We also calculated correlation coefficients between the key variables and controls (Tables S2 and S3 in the Appendix). It can be seen that none of the variables are highly correlated with one another.

${ }^{4}$ For each precolonial institution, we calculated the fraction of the area covered by each ecoregion using Africa Albers Equal projection. We used these fractions to determine the predominant ecoregion in each precolonial institution.
} 


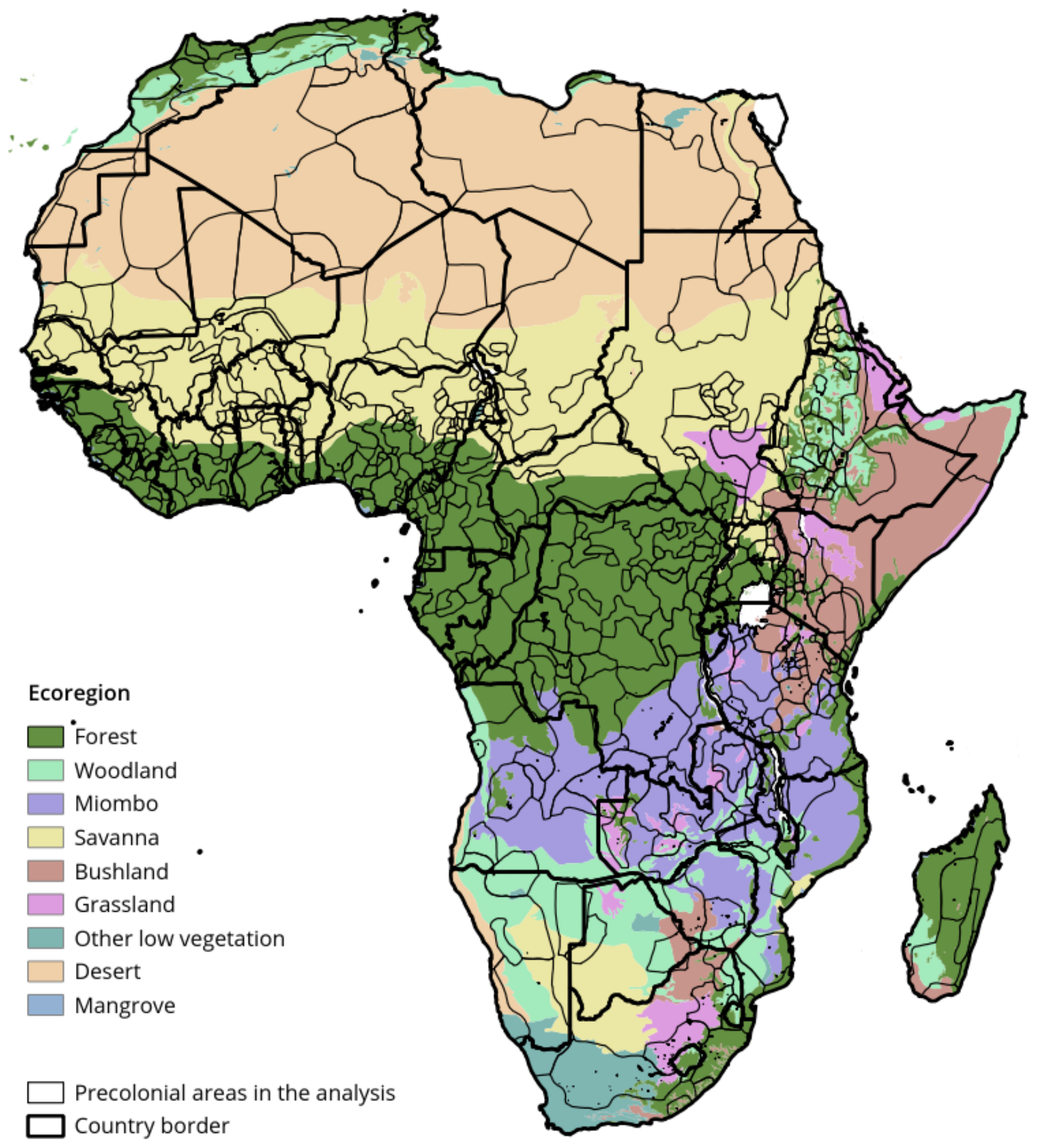




\section{Theory}

Our empirical analysis is based on the hypothesis that precolonial institutions continue to impact on natural resource management in Africa. From the introduction, it is known that precolonial institutions closely relate to current measures of economic activity and that local village leaders often continue to control access to land and forest resources under the continued and widespread use of communal forest institutions across Africa. Therefore, if precolonial institutions continue to play a meaningful role in forest protection and exploitation, we content that different forms of precolonial institutions should be related to current rates of deforestation.

While an explanation has been provided for why we can expect precolonial institutions to persist to current times and play an important role in forest management, it does not explain why the different succession rules of village heads chiefs should be related to current rates of deforestation. We suggest that there are two potential transmission mechanisms. The first is that the succession rules provide a proxy for institutional checks and balances on local village heads that may see some more prone to engage in deforestation than others. The second is that the succession rules provide a proxy for property rights uncertainty and internal conflict that may generate higher or lower levels of deforestation. As will be evident from the discussion below, neither mechanism is mutually exclusive.

Consistent with the findings of Acemoglu et al. (2014) we hypothesize that local village leaders with fewer institutional checks on their power are more prone to exploit (or fail to protect) local forests, which according to Alesina et al. (2014) have community public good attributes. The precolonial succession rules for local village heads fall under the following four categories: hereditary, democratic, from above, and social standing (discussed in more detail below). We use these succession rules as a proxy for contemporary institutional checks on village heads. Specifically, compared to the base case of hereditary succession we consider that village chiefs who were elected by 'social standing' to be the most unaccountable and lacking the most authority, and therefore prone to exploitative practices. We hypothesise that this form of succession is the most prone to strategic manipulation and patrimonial practices. Patrimonial practices require rents for distribution in exchange for political support, and forest exploitation is an important source of such rents (see Richards 1998). We hypothesise that village chiefs who 
were 'elected from above' should be more institutionally checked than the base case of hereditary succession, and therefore manage the forest resources in a more sustainable manner. This is so as chiefs appointed from above face the risk of dismissal from a paramount chief (from above) for poor or corrupt performance. Indeed, it is the view of Herbst (2000) that local chiefs were more accountable where they faced oversight from above.

We consider that chiefs who were 'democratically elected' to be the intermediate case in terms of their relationship with deforestation; situated between those appointed through social standing and those appointed from above. On the one hand democratically elected chiefs face an important institutional check in the form of the risk of electoral loss for poor performance or corrupt behaviour; however they may also be prone to engage in patrimonial practices to gain or remain in power. On this point, Klopp (2012) argues that more political competition can require greater resources to secure tenure (in terms of campaign funds and distributing largesse in return for support) and those in power exploit forest resources while they can (knowing that they may lose tenure in the next election). Furthermore, democratically elected chiefs may be more willing to act on the preferences of their constituents who may prefer to trade-off short term consumption for long-term welfare, as identified by Nordhaus (1975).

The other potential mechanism underlying the link between village head succession rules and deforestation is that different sources of authority among village heads may generate more uncertainty and conflict over natural resource use rights. Consistent with the findings of Filer (2012) and Larcom (2015) we also hypothesize that where local leaders have less concrete sources of authority, there will be more conflict and uncertainty over property rights that can devalue forest resources and make co-ordination against outsiders wishing to exploit their resources more difficult.

A useful way to consider forest governance in Africa (and much of the developing world) is through the concept of legal pluralism. It implies that multiple institutional regimes can coexist in the same place and can enforce their own rules on the same people and resources (Griffiths 1986). In a legally pluralistic environment, where there may be multiple ownership rights issued over the same natural resource, uncertainty can be generated both within the local group and between the local group and other groups or actors. In terms of ownership disputes within a 
local group, multiple families or individuals within the same community may lay claim to the same piece of land (and trees). In terms of ownership disputes between groups or actors, this can occur when state ownership rights conflict with customary ownership rights. This is especially the case when local resource owners have not been adequately compensated for the transfer of their traditional resources to the state or some other entity, or when ownership rights over natural resources are deemed to be inalienable by their customary owners (even if they were previously 'sold' in the past). This conflict can lead to uncertainty over ownership, to devaluation of the natural resource among all those who claim it, and to encourage those who have access to exploit it when they have the chance. Disputed ownership may also increase co-ordination costs and reduce the incentives to protect forests from outsiders who wish to exploit forests for timber, whether they are logging companies or corrupt state officials (Alesina et al. 2014). Such a hypothesis is also consistent with the findings of Deacon (1996), who considers that instability and conflict leads to less secure land tenure; seeing users more willing to exploit forest resources and less willing to take long term investments. In terms of succession rules, we can expect some to be more likely to generate uncertainty over ownership rights than others. Compared to the base case of hereditary appointment, those village chiefs appointed from above should have more legitimacy than those appointed by social status, which almost by definition involves the distribution of patrimonial largesse. Furthermore, we can expect those appointed from above can call upon, and draw upon the authority of paramount chiefs, when ownership disputes arise.

\section{Results}

Table 2 presents the least squares estimates for precolonial institutions and deforestation in Africa. Compared to the base case of hereditary succession, the coefficient for precolonial societies where village heads were appointed from above (usually by paramount chiefs) is positive and significant across most specifications. As can be seen from Column 1, the coefficient is negative with a value of -0.627 and significant at the 1 per cent level with the absence of any controls. However, as can be seen from Columns 2 to 6, when the controls are added the coefficient falls in value by almost two thirds. Our preferred specification includes country fixed effects and with all the controls at the precolonial level, and can be found in

Column 6. It can also be seen that this specification has a much higher R-squared than the other 
specifications; 0.406, indicating goodness of fit. In Column 6, it can be seen that the coefficient for appointment from above is -0.297 and significant at the 5 per cent level. This indicates that the regions where local leaders were appointed from above in precolonial times have approximately 0.297 percentage points increase in forest cover (compared to the base case of hereditary succession) over the period 2000 to 2012. Given that mean deforestation across all regions was 1.090 per cent for the same period, this suggests that the magnitude of this relationship between the appointment from above and deforestation is substantial. The coefficients of the two other modes of appointment (democratic and social standing) are positive (indicating higher levels of deforestation compared to the basecase of hereditary succession) but not statistically significant. It can also be seen that the coefficient for the degree of precolonial political centralization is statistically insignificant, and approximating zero for our preferred specification.

Table 2: Precolonial institutions and deforestation in Africa

\begin{tabular}{|c|c|c|c|c|c|c|}
\hline & $(1)$ & (2) & (3) & (4) & $(5)$ & $(6)$ \\
\hline \multicolumn{7}{|l|}{ Local precolonial institutions } \\
\hline Democratic election & $\begin{array}{c}-0.197 \\
(0.250)\end{array}$ & $\begin{array}{c}0.086 \\
(0.184)\end{array}$ & $\begin{array}{c}0.083 \\
(0.182)\end{array}$ & $\begin{array}{c}0.079 \\
(0.169)\end{array}$ & $\begin{array}{c}0.083 \\
(0.168)\end{array}$ & $\begin{array}{c}0.246 \\
(0.169)\end{array}$ \\
\hline Election from above & $\begin{array}{c}-0.627 * * * \\
(0.214)\end{array}$ & $\begin{array}{l}-0.207 \\
(0.126)\end{array}$ & $\begin{array}{l}-0.227^{*} \\
(0.135)\end{array}$ & $\begin{array}{l}-0.247 * \\
(0.137)\end{array}$ & $\begin{array}{l}-0.248^{*} \\
(0.137)\end{array}$ & $\begin{array}{c}-0.297 * * \\
(0.119)\end{array}$ \\
\hline Election by social standing & $\begin{array}{l}-0.135 \\
(0.305)\end{array}$ & $\begin{array}{l}-0.016 \\
(0.260)\end{array}$ & $\begin{array}{l}-0.007 \\
(0.262)\end{array}$ & $\begin{array}{l}-0.035 \\
(0.273)\end{array}$ & $\begin{array}{l}-0.017 \\
(0.271)\end{array}$ & $\begin{array}{c}0.006 \\
(0.270)\end{array}$ \\
\hline Political centralization & & & $\begin{array}{c}0.043 \\
(0.153)\end{array}$ & $\begin{array}{c}0.041 \\
(0.146)\end{array}$ & $\begin{array}{c}0.031 \\
(0.145)\end{array}$ & $\begin{array}{l}-0.001 \\
(0.125)\end{array}$ \\
\hline$R^{\wedge} 2$ & 0.011 & 0.248 & 0.248 & 0.245 & 0.246 & 0.406 \\
\hline Colonial institutions & No & No & No & Yes & Yes & No \\
\hline Current institutions & No & No & No & No & Yes & Yes \\
\hline Population density & No & Yes & Yes & Yes & Yes & Yes \\
\hline Geographic controls & No & Yes & Yes & Yes & Yes & Yes \\
\hline Economic development controls & No & Yes & Yes & Yes & Yes & Yes \\
\hline Forest stock control & No & Yes & Yes & Yes & Yes & Yes \\
\hline Country fixed effects & No & No & No & No & No & Yes \\
\hline Observations & 645 & 645 & 645 & 632 & 632 & 642 \\
\hline
\end{tabular}

Table 2 presents OLS estimates of local precolonial institutions (village head succession rules) with deforestation for 2000 to 2012, with double-clustered standard errors in the parentheses for the continent of Africa.***,**, and * indicate statistical significance at the 1 per cent, 5 per cent and 10 per cent level. The base category of chiefs is hereditary succession. Political centralization is a binary variable where a value of 0 represents a fragmented society and a value of 1 represents a centralized society. Colonial institutions include Colonial Duration, Indirect Rule and Colonial Intensity. Current institutions include Rule of Law and Protected Areas. Controls are as follows: Population density; Geographic Controls (Vegetation Zones, Distance to sea, Distance from national border, Distance from 
capital city, Longitude and Latitude, Land suitability for agriculture, Elevation, Malaria stability index); Economic Development Controls (Light density); Forest stock controls (forest area in 2000). As our colonial institutional measures and rule of law have zero within standard deviation, we are unable to include country fixed effects in estimations (1)-(5). For estimation (6), current institutions is limited to Protected Areas only.

While there are large forested regions in Africa (mainly located around the equator but also at the very north of the continent; see Figure 3) there are also vast arid regions and large tracts of scrub and woodlands. Given our interest in deforestation, and therefore to focus our analysis on the forested regions of Africa, we replicate the above estimations solely on those areas where forests predominate and results are shown in Table 3. We consider this targeted analysis to be superior and less prone to measurement error, although it does come with a cost of a reduced number of observations (falling from 642 for the whole of the continent to 273 when just including forests).

Compared to the base case of hereditary succession, the coefficient for precolonial regions where village heads were appointed through social standing is positive and highly significant across most specifications (see Table 3). As can be seen from Column 1, the coefficient is positive with a value of 0.815 . The coefficient for precolonial regions where village heads were appointed from above is negative and significant, with a value of -0.832 in the absence of any controls. However, when the controls are added (Columns 2 to 6) the coefficient falls in value considerably while the standard errors increase. As a result this measure loses its statistical significance. Once more, the coefficient for the degree of precolonial political centralization is statistically insignificant across all specifications.

In the most comprehensive specification, that includes country fixed effects and all controls at the precolonial level (Column 6), the coefficient for local leaders appointed by social standing is 0.789 and significant at the 5 per cent level. This suggests that the regions where local leaders were appointed by social standing in precolonial times have approximately 0.8 percent points more deforestation (compared to the base case of hereditary succession) over the period 2000 to 2012. Given the magnitude of this coefficient compared to the mean deforestation for forested regions for the same period (approximately 1.6 per cent), the statistical relationship is not only significant, but also of large magnitude. The coefficients of the other mode of appointment (democratic succession) are consistently positively signed but only statistically significant at the 10 per cent level (under our preferred specification in Column 6) with a coefficient of 0.535. In 
summary, precolonial succession rules of local village heads are shown to have a significant relationship (both in terms of statistical significance and magnitude) with measures of deforestation in Africa over the period of 2000 to 2012.

Table 3: Precolonial institutions and deforestation in designated forests

\begin{tabular}{lcccccc}
\hline & $(1)$ & $(2)$ & $(3)$ & $(4)$ & $(5)$ & $(6)$ \\
\hline & & & & & & \\
Local precolonial institutions & & & & & & \\
Democratic election & 0.623 & 0.626 & 0.610 & $0.559^{*}$ & 0.556 & $0.535^{*}$ \\
& $(0.466)$ & $(0.386)$ & $(0.385)$ & $(0.330)$ & $(0.342)$ & $(0.306)$ \\
Election from above & $-0.832^{* * *}$ & 0.153 & 0.151 & 0.108 & 0.134 & -0.465 \\
& $(0.301)$ & $(0.301)$ & $(0.341)$ & $(0.394)$ & $(0.400)$ & $(0.413)$ \\
Election by social standing & $0.815^{*}$ & $0.919^{* * *}$ & $0.916^{* * *}$ & $0.903^{* *}$ & $0.853^{* *}$ & $0.789^{* *}$ \\
& $(0.430)$ & $(0.327)$ & $(0.328)$ & $(0.357)$ & $(0.357)$ & $(0.372)$ \\
& & & & & & \\
Political centralization & & & 0.001 & 0.057 & 0.096 & 0.152 \\
& & & $(0.245)$ & $(0.226)$ & $(0.211)$ & $(0.262)$ \\
& & & & & \\
$\mathrm{R}^{\wedge} 2$ & & & & & \\
Colonial institutions & No & No & No & Yes & Yes & 0.497 \\
Current institutions & No & No & No & No & Yes & Yes \\
Population density & Yes & Yes & Yes & Yes & Yes \\
Geographic controls & No & Yes & Yes & Yes & Yes & Yes \\
Economic development controls & No & Yes & Yes & Yes & Yes & Yes \\
Forest stock control & No & Yes & Yes & Yes & Yes & Yes \\
Country fixed effects & No & No & No & No & No & Yes \\
Observations & 273 & 273 & 273 & 273 & 273 & 273 \\
\hline
\end{tabular}

Table 3 presents OLS estimates of local precolonial institutions (village head succession rules) with deforestation for 2000 to 2012, with double-clustered standard errors in the parentheses for the continent of Africa.***,**, and * indicate statistical significance at the 1 per cent, 5 per cent and 10 per cent level. The base category of chiefs is hereditary succession. Political centralization is a binary variable where a value of 0 represents a fragmented society and a value of 1 represents a centralized society. Colonial institutions include Colonial Duration, Indirect Rule and Colonial Intensity. Current institutions include Rule of Law and Protected Areas. Controls are as follows: Population density; Geographic Controls (Vegetation Zones, Distance to sea, Distance from national border, Distance from capital city, Longitude and Latitude, Land suitability for agriculture, Elevation, Malaria stability index); Economic Development Controls (Light density); Forest stock controls (forest area in 2000). As our colonial institutional measures and rule of law have zero within standard deviation, we are unable to include country fixed effects in estimations (1)-(5). For estimation (6), current institutions is limited to Protected Areas only.

\subsection{Robustness tests}

While the results above demonstrate a strong statistical relationship with local precolonial institutions and current levels of deforestation, it is acknowledged that the Hansen et al. (2013) 
measure for deforestation (forest loss) may not be beyond criticism and that the start and end dates (2000-2012) are somewhat arbitrary. Therefore, as a test for robustness of these results we also ran the equations using a measure of deforestation that we generated using tree cover data available for the period 2003 to 2008.

We derived this variable by reclassifying percent tree cover data (ISCGM 2013) into forest and non-forest, using a threshold of at least 30 per cent of tree cover for a pixel to be considered forest (Couturier et al. 2012; Bodart et al. 2013; Mayaux et al. 2013). We used this binary classification of forest cover to calculate the fraction of forested area in each precolonial society for the years 2003 and 2008 and then calculated the difference between both values for each precolonial society. Tree cover data in raster format were obtained from ISCGM (2013) who derived them from MODIS images. The tree cover rasters have a resolution of 30 and 15 arcseconds for each year respectively (500m and $1 \mathrm{~km}$ approximately) and each pixel represents the percentage of canopy cover in a range from 0 to 100 per cent. Mean deforestation of this measure for the continent as a whole is 1.694 per cent, which is approximately a third higher than the Hansen et. al. (2013) data and has a much higher variance (with a standard deviation of 23.796 per cent and with a maximum of 74.38 per cent deforestation and 71.61 per cent of forest increase.

The results of the equations above using the alternative measure for deforestation with a shortened timeframe are presented in Tables 4 and 5 below. Table 4 presents the regression results for the whole continent while Table 5 presents the results only for those regions where forests predominate. The results are reassuringly similar in terms of precolonial institutions. We find that compared to the base case of hereditary rule, areas where village heads were appointed by social standing are consistently positive and statistically significant. However, it should be noted that the absolute magnitudes are considerably higher than those estimated using the Hansen et. al. (2013) data; 7.500 for the continent as a whole and 8.226 for forested regions, but so are the standard errors. These higher magnitudes should be taken with some caution and can be partly explained by the much higher degree of variance in deforestation rates contained in this alternative data set. Most importantly, these results generated from an alternative data source confirm the strong statistical relationship between local precolonial institutions and recent deforestation. 
Table 4: Precolonial institutions and deforestation in Africa: alternative data for deforestation

\section{(1)}

\section{Local precolonial institutions}

Democratic election

Election from above

Election by social standing

Political centralization

$\mathrm{R}^{\wedge} 2$

Colonial institutions

Current institutions

Population density

Geographic controls

Economic development controls

Forest stock control

Country fixed effects

Observations
(2)

(3)

(4)

(5)

(6)

$\begin{array}{cccccc}1.141 & 1.602 & 1.819 & 1.653 & 1.468 & -0.431 \\ (4.249) & (2.579) & (2.525) & (2.437) & (2.478) & (1.878) \\ -3.380 & 2.157 & 3.421 & 2.528 & 2.319 & -0.323 \\ (5.01) & (3.959) & (3.864) & (3.802) & (3.998) & (2.310) \\ 12.253^{* *} & 13.009^{* * *} & 12.459^{* * *} & 11.563^{* *} & 11.591 * * * & 7.500^{* * *} \\ (5.700) & (4.037) & (4.070) & (4.492) & (4.353) & (3.523)\end{array}$

$-2.810$

(2.110)

$-2.509$

$-2.594$

(1.869)

$-2.022$

(1.318)

0.460
No
No
Yes
Yes
Yes
Yes
No
645

0.494
Yes
No
Yes
Yes
Yes
Yes
No
632

0.512
Yes
Yes
Yes
Yes
Yes
Yes
No
632

0.689

No

Yes

Yes

Yes

Yes

Yes

Yes

642

Table 4 presents OLS estimates of local precolonial institutions (village head succession rules) with an alternative measure of deforestation for 2003 to 2008, with double-clustered standard errors in the parentheses for the whole of Africa. ***, **, and * indicate statistical significance at the 1 per cent, 5 per cent and 10 per cent level. The base category of chiefs is hereditary succession. Political centralization is a binary variable where a value of 0 represents a fragmented society and a value of 1 represents a centralized society. Colonial institutions include Colonial Duration, Indirect Rule and Colonial Intensity. Current institutions include Rule of Law and Protected Areas. Controls are as follows: Population density; Geographic Controls (Vegetation Zones, Distance to sea, Distance from national border, Distance from capital city, Longitude and Latitude, Land suitability for agriculture, Elevation, Malaria stability index); Economic Development Controls (Light density); Forest stock controls (forest area in 2003). As our colonial institutional measures and rule of law have zero within standard deviation, we are unable to include country fixed effects in estimations (1)-(5). For estimation (6), current institutions is limited to Protected Areas only.

\section{Table 5: Precolonial institutions and deforestation in designated forests: alternative data}

\section{for deforestation}

\section{Local precolonial institutions}

Democratic election

Election from above
(1)

(2)

$\begin{array}{cc}5.214 & 5.773 \\ (5.539) & (4.805) \\ 1.400 & -0.424 \\ (14.694) & (8.314)\end{array}$

(3)

5.300
$(4.788)$
-0.387
$(8.186)$

(4)

3.416
$(4.287)$
-3.017
$(6.809)$

(5)

(6)

$\begin{array}{cc}3.319 & 3.472 \\ (4.478) & (3.935) \\ -3.136 & -2.844 \\ (6.551) & (8.611)\end{array}$




\begin{tabular}{lcccccc} 
Election by social standing & $\begin{array}{c}17.429^{* *} \\
(8.740)\end{array}$ & $\begin{array}{c}12.968^{* *} \\
(5.331)\end{array}$ & $\begin{array}{c}12.774^{* *} \\
(5.249)\end{array}$ & $\begin{array}{c}10.236^{* *} \\
(4.541)\end{array}$ & $\begin{array}{c}9.611^{* *} \\
(4.732)\end{array}$ & $\begin{array}{c}8.226^{*} \\
(4.805)\end{array}$ \\
Political centralization & & & & & & \\
& & & -0.260 & 0.675 & 0.537 & 1.970 \\
& & & $(2.748)$ & $(2.349)$ & $(2.652)$ & $(2.581)$ \\
$\mathrm{R}^{\wedge} 2$ & 0.021 & 0.477 & 0.482 & 0.524 & 0.529 & 0.678 \\
Colonial institutions & No & No & No & Yes & Yes & No \\
Current institutions & No & No & No & No & Yes & Yes \\
Population density & No & Yes & Yes & Yes & Yes & Yes \\
Geographic controls & No & Yes & Yes & Yes & Yes & Yes \\
Economic development controls & No & Yes & Yes & Yes & Yes & Yes \\
Forest stock control & No & Yes & Yes & Yes & Yes & Yes \\
Country fixed effects & No & No & No & No & No & Yes \\
Observations & 272 & 272 & 272 & 272 & 272 & 272 \\
\hline
\end{tabular}

Table 5 presents OLS estimates of local precolonial institutions (village head succession rules) with an alternative measure of deforestation for 2003 to 2008, with double-clustered standard errors in the parentheses for the whole of Africa. ***, **, and * indicate statistical significance at the 1 per cent, 5 per cent and 10 per cent level. The base category of chiefs is hereditary succession. Political centralization is a binary variable where a value of 0 represents a fragmented society and a value of 1 represents a centralized society. Colonial institutions include Colonial Duration, Indirect Rule and Colonial Intensity. Current institutions include Rule of Law and Protected Areas. Controls are as follows: Population density; Geographic Controls (Vegetation Zones, Distance to sea, Distance from national border, Distance from capital city, Longitude and Latitude, Land suitability for agriculture, Elevation, Malaria stability index); Economic Development Controls (Light density); Forest stock controls (forest area in 2003). As our colonial institutional measures and rule of law have zero within standard deviation, we are unable to include country fixed effects in estimations (1)-(5). For estimation (6), current institutions is limited to Protected Areas only.

\section{Discussion}

Our results provide striking evidence of an enduring relationship between precolonial institutions and current rates of deforestation in Africa. They suggest that village heads still continue to control access to natural resources in Africa, and that the institutions that govern their tenure have an important impact on environmental outcomes. We find that local village head succession rules have a strong statistical relationship with current rates of deforestation. In particular, we find near consistent results that those areas where village heads (or chiefs) were known to be appointed by 'social standing' have higher current rates of deforestation compared to the base case of hereditary succession. We also find some evidence that those societies where local village heads were appointed from above (normally by a paramount chief) have lower current rates of deforestation. Finally, the results also show that democratic succession is associated with higher levels of deforestation compared to the base case of hereditary rule. 
It must be stressed that these findings are generated while controlling for a multitude of variables that are known to be, or are likely to be, associated with deforestation. These include the existing forest stock (the percent of forest cover in each precolonial region in 2000) and therefore controlling for the relative scarcity or abundance of forest resources in each of the local communities; and per cent of protected areas in each precolonial region. These are in addition to various other known and potential drivers of deforestation that include: type of vegetation, population density, distance to markets, longitude and latitude, suitability of land to agriculture, elevation (that is known to be correlated with ethnic fractionalization, see Michalopoulos 2012), malaria suitability, and light density at night (which is an established proxy for economic development, see Michalopoulos and Papaioannou 2013, 2014). Finally, we also control for current and colonial institutions (rule of law index and the type and intensity of colonial rule) and country fixed effects (which enable us to account for all country specific, time invariant factors).

Our results are consistent with a number of recent works that find a statistical link between precolonial institutions to current measures of institutional quality. Many of these works highlight the fact that, especially in rural areas, many African states have a limited reach and therefore local institutions (which are often non-state) play an important role in public good provision. While most of these works have focused on the degree of political centralization found among precolonial societies, Guiliano and Nunn (2013) also focused on local precolonial institutions. In their case they found a positive link between democratic succession at the village level and democratic institutions at the national level. Where this paper differs from the current literature that links precolonial institutions and current measures of institutional quality is that it concerns natural resource management, namely deforestation. Therefore, the remainder of this discussion section contextualizes the results and provides guidance for policy makers.

The concept of legal pluralism suggests that state and non-state regulators can coexist in the same regulatory space, and our results suggest this is the case in the governance of forests. In this sense, our results in no way imply that state institutions are irrelevant. Indeed, while not reported (in order to focus the analysis on precolonial institutions) the coefficient for the percentage of protected areas in each precolonial region is negative and highly significant 
(suggesting that protected areas are associated with a reduction in deforestation). ${ }^{5}$ More generally, the seminal works of Acemoglu et al. (2000, 2002) and La Porta et al. (2001) and the literature that these works have generated has highlighted the importance, across a wide range of measures of institutional efficiency, of Africa's state institutions and their colonial legacy. Rather, our results suggest that any comprehensive analysis of institutional outcomes in rural Africa, especially those concerning natural resource management where local non-state leadership is known to continue to play an important role, must adequately consider and measure both state and non-state institutions. In terms of natural resource management, our results are consistent with the broad findings of Meinzen-Dick and Pradhan (2001: 11) who conclude that ' $[\mathrm{t}]$ he state is one important legitimating institution, but it is not the only one, and in many cases it may not be as relevant as a village, an ethnic group or a users' group.' As outlined in the introduction, the institutional literature relating to forest management in Africa suggests that traditional leadership structures persist and continue to play an important role. In a practical sense this can see village heads call upon their traditional control rights in relation to the use and rationing of forest resources.

In Africa, the most common form of interaction between state and non-state institutions is one where the state recognizes and aims to incorporate traditional authority figures into its own system in return for subordination, or indirect rule (Mandami 1996). By subordinating themselves to the state, traditional leaders can gain legitimacy, protection and access to the state's resources (including force). While indirect rule was a common colonial practice, it continues well into the post-colonial era and the vast majority of African states have enshrined traditional leadership structures into their constitutions and legal systems (see Herbst 2000). Indirect rule has enabled many precolonial institutions survive and even grow in strength, both in the colonial and precolonial era (Mandami 1996, Acemoglu et al. 2014). Given the limited capacity of the state in many parts of rural Africa and that significant numbers of people living within or on the borders of state protected forests, cooperation with, or direct enforcement of, state protections by traditional leadership is often an important element of forest protection

\footnotetext{
${ }^{5}$ Consistent with our results Green et al. (2013) have found state parks in Africa to be (partially) effective reducing forest loss. More generally, while the literature on protected areas is contentious, not least due to issues of selection bias and endogeneity, they do seem to be at least partially effective in forest protection (see Pfaff et al .2014, Joppa and Pfaff 2010 and Campbell et al. 2008). In relation to state versus non-state protections, Hays (2006) and Bray et al. (2008), have shown that forests protected by informal rules and non-state grouping (e.g. community forests) achieve similar outcomes as forests protected by state legislation (e.g. national parks).
} 
policy (see Adams and Hulme 2001 and Fabricius et al. 2013). With the practice of indirect rule and the limited capacity of the state more generally, local leaders are often left unobserved by central authorities. These results provide important guidance for those concerned with forest conservation toward local institutions (whether they be officially recognized by the state or not) where local leaders are appointed by social status as, all things being equal, they are experiencing much faster deforestation than other areas.

In terms of succession rules being a proxy for institutional checks and balances on local leaders, our empirical results are consistent with this interpretation. Those areas where chiefs were known to be appointed by 'social standing' are associated with higher levels of deforestation. These are institutions that we have hypothesized to be the most susceptible to corrupt and patrimonial practices, and that could see resource rents used for personal benefit or selectively distributed in exchange for support. Indeed, engaging in deforestation (or allowing it for payment) is one possible source of rent that can be used to generate or maintain local level political support. We also find some evidence that those areas where village heads were appointed from above are associated with lower levels of deforestation. Again, these results are consistent with our institutional analysis that leaders with more institutional checks over their control of local public goods should be associated with forest conservation. In terms of democratic succession, our results suggest that any beneficial effects generated from strictures of democratic governance are outweighed by the tendency for democratically elected chiefs to engage in patrimonial behaviour or that that there is a preference among local communities to trade-off short term consumption for long-term welfare (which is being operationalized by the local leadership). Our results are also in-line with the other potential transmission mechanism identified; the degree to which leaders with less concrete authority generate conflict and uncertainty over property rights, which in turn devalues them and makes co-ordination against outsiders wishing to exploit them more difficult. However, little further can be said on whether this mechanism is more or less relevant because the rankings in terms of their effects of deforestation are virtually equivalent to the institutional checks and balances mechanism. Therefore, gaining a better understanding of these more complex channels of influence (and of the interactions of different sets of institutional frameworks) would seem to be the next step in understanding the role that legal pluralism plays in relation to deforestation in Africa. 


\section{Conclusion}

There is a growing awareness that precolonial institutions continue to impact current measures of institutional efficiency in Africa and the developing world. This is the first investigation that we are aware of that links precolonial institutions with deforestation. We find that areas where local leaders were appointed through 'social standing' in precolonial times are associated with higher current levels of deforestation. While these results are new to the literature, they should not be entirely unexpected. Local leaders in Africa are often still vested with resource control rights that can directly affect forest management and the rate of deforestation. In such an institutional context, we can expect non-state resource controllers with fewer institutional checks to be more prone to engage in self-interested rent extraction policies, which can lead to higher rates of deforestation. We can also expect more ownership disputes in areas where the legitimacy of local leaders is weaker and requires patrimonial largesse.

Deforestation continues to be a major source of greenhouse gas emissions, biodiversity loss and habitat destruction in Africa, despite concerted efforts from the international community, national governments and the Green Belt movement to halt it. While these efforts should be continued, these findings suggest that local institutions (some of them which may not be easily observable by national governments or the casual observer) play an important role in deforestation. Gaining a better understanding of the channels of influence between the legacy of precolonial institutions and forest management (and the interactions of different sets of institutional frameworks) is the next step in understanding the role that institutions play in relation to understanding and reducing deforestation in Africa, and the developing world more generally. Indeed, acknowledging the specific influence of local institutions on forest conservation, as produced by historical institutional pathways and legal pluralism more generally, could be the missing link in finally halting large scale deforestation in Africa. 


\section{ACKNOWLEDGMENTS}

We are grateful to Stelios Michalopoulos and Elias Papaioannou for making their light density at night data available to us, Nathan Nunn for his the digitized version of Murdock's pre-colonial map; Patrick Ziltener and Daniel Kuenzler for making their colonial data available; and finally we thank the Geospatial Information Authority of Japan, Chiba University and collaborating organizations, for making the Global Percent Tree Cover Map available. We would also like to thank Elias Papaioannou, Hanspeter Muller, Colin Poulton, Tim Willems, and seminar participants at the 16th annual BioEcon conference at Kings College Cambridge and at the Grantham Institute at the London School of Economics for their comments, with the usual disclaimer applying. We would like to thank the anonymous referees for their very helpful comments. Finally, we also thank Dennis Piva for technical assistance in the preparation of this manuscript. 


\section{BIBLIOGRAPHY}

Adams, W., and D. Hulme. 2001. If community conservation is the answer in Africa, what is the question? Oryx 35(3), 193-200.

Alesina, A., C. Gennaioli, and S. Lovo. 2014. Public goods and ethnic diversity: evidence from deforestation in Indonesia. NBER Working Paper (No. w20504).

Acemoglu, D., S. Johnson, and J. A. Robinson. 2000. The colonial origins of comparative development: an empirical investigation. NBER Working Paper (No. w7771).

Acemoglu, D., S. Johnson, and J. A. Robinson. 2002. Reversal of fortune: Geography and institutions in the making of the modern world income distribution. The Quart. J. of Econ., 117(4), 1231-1294.

Acemoglu, D., T. Reed, and J. A. Robinson. 2014. Chiefs: Economic Development and elite control of civil society in Sierra Leone. J. of Pol. Econ. 122(2), 319-368.

Barbier, E. B., and J. C. Burgess. 2001. The Economics of tropical deforestation. J. of Econ. Surv. 15(3), 413-433.

Bodart, C., A. B. Brink, F. Donnay, A. Lupi, P. Mayaux, and F. Achard. 2013. Continental estimates of forest cover and forest cover changes in the dry ecosystems of Africa between 1990 and 2000. J. of Biogeography 40(6), 1036-1047.

Bray, D. B., E. Duran, V. Ramos, J. Mas, A. Velazquez, R. Balas McNab, D. Barry, and J. Radachowsky. 2008. Tropical deforestation, community forests, and protected areas in the Maya Forest. Ecol. and Soc., 13(2), 56.

Brown, E., and J. Makana. 2014. Experience from a pilot project to improve forest governance in the artisanal logging sector in northeastern Democratic Republic of Congo. 
http://www.cifor.org/publications/pdf_files/events/montpellier/scientific-

session/Presentations/Session\%2014/Ellen\%20Brown_Makana_artisanal_logging_DRC_all.pdf

Bruner, A., R. Gullison, R. Rice, and G. Da Fonseca. 2001. Effectiveness of parks in protecting tropical biodiversity. Sci., 291(5501), 125-128.

Burgess, R., M. Hansen, B. A. Olken, P. Potapov, and S. Sieber. 2012. The political economy of deforestation in the tropics. The Quart. J. of Econ., 2012.127(4), 1707-1754.

Campbell, A., S. Clark, L. Coad, L. Miles, K. Bolt, and D. Roe. 2008. Protecting the future: Carbon, forests, protected areas and local livelihoods. Biodiversity, 9(3-4), 117-121.

Cameron, A., J. Gelbach, and D. Miller. 2011. Robust inference with multiway clustering. J. of Bus. \& Econ. Stats., 29(2), 238-249.

Center for International Earth Sci. Information Network - CIESIN - Columbia University, Global Roads Open Access Data Set, Version 1 (gROADSv1). 2013. NASA SocioEcon. Data and Applications Center (SEDAC): Palisades, NY.

Couturier, S., J. Núñez, and M. Kolb. 2012. Measuring Tropical Deforestation with Error Margins: A Method for REDD Monitoring in South-Eastern Mexico. In Tropical Forests, P. Sudarshana, M. Nageswara-Rao, and J.R. Soneji, eds. (InTech).

Deacon, R. 1996. Deforestation, investment, and political stability. New York: Cambridge University Press.

DeFries, R., T. Rudel, M. Uriarte, and M. Hansen. 2010. Deforestation driven by urban population growth and agricultural trade in the twenty-first century. Nat. GeoSci., 3(3), 178-181. 
Ensminger, J. 1997. Changing property rights: Reconciling formal and informal rights to land in Africa." The frontiers of the new institutional economics, in Drobak, J, and J. Nye. The frontiers of the new institutional economics, 165-196. Accademic Press: San Deigo.

Fabricius, C., E. Koch, S. Turner, and H. Magome, eds. 2013. Rights resources and rural Development: Community-based natural resource management in Southern Africa. Routledge: London.

FAO. 2010. Global forest resources assessment 2010: Key Findings, FAO: Rome.

Fenske, J. 2013. Does land abundance explain African institutions? The Econ. J. 123(573), 1363-1390.

Fenske, J. 2014. Ecology, Trade, and States in Pre-Colonial Africa. J. of the Eur. Econ. Assoc. $12(3), 612-640$.

Filer, C. 2012. Why green grabs don't work in Papua New Guinea. J. of Peasant Stud., 39(2), 599-617.

Green, J., C. Larrosa, N. D. Burgess, A. Balmford, Alison Johnston, Boniface P. Mbilinyi, Philip J. Platts, and Lauren Coad. 2013. Biol. Conserv., 164, 62-72.

Gennaioli, N., and I. Rainer. 2007. The modern impact of precolonial centralization in Africa. $J$. of Econ. Growth, 12(3), 185-234.

Geist, H. and E. Lambin. 2002. Proximate Causes and Underlying Driving Forces of Tropical Deforestation: Tropical forests are disappearing as the result of many pressures, both local and regional, acting in various combinations in different geographical locations. BioSci., 2002, 52.2: 143-150. 
Griffiths, J. 1986. What is legal pluralism? The J. of Leg. Pluralism and Unofficial law, 18(24), $1-55$.

Hansen, M. C., Potapov, P. V., Moore, R., Hancher, M., Turubanova, S. A., Tyukavina, A., ... \& Townshend, J. R. G. 2013. High-resolution global maps of 21st-century forest cover change. Sci., 342(6160), 850-853.

Hayes, T. 2006. Parks, people, and forest protection: an institutional assessment of the effectiveness of protected areas. World Dev., 34(12), 2064-2075.

Herbst, J. 2000. States and power in Africa: comparative lessons in authority and control. Princeton University Press.

ISCGM. 2013. Global Percent Tree Cover. International Steering Committee for Global Mapping and Geospatial Information Authority of Japan, Chiba University. Available from http://www.iscgm.org/ [Downloaded on December 2013]

Joppa, L., and A. Pfaff. 2011. Global protected area impacts. Proc. of the R. Soc. B: Biol. Sci., 278(1712), 1633-1638.

Kaufmann, D., and A. Kraay. 2008. Governance indicators: Where are we, where should we be going? The World Bank Res. Obs., 23(1), 1-30.

Kiszewski, A., A. Mellinger, A. Spielman, P. Malaney, S. Sachs, and J. Sachs. 2004. A global index representing the stability of malaria transmission. Am. J. of Tropical Med. and Hyg.,70(5), 486-498.

Klopp, J. 2012. Deforestation and democratization: patronage, politics and forests in Kenya, $J$. of East. Afr. Stud., 6(2), 351-370 
La Porta, R., F. Lopez-de-Silanes, A. Shleifer, and R. W. Vishny. 2001. Law and Fin. Springer Berlin Heidelberg.

Larcom, S. 2013. Accounting for legal pluralism: the impact of precolonial institutions on crime. The Law and Dev. Rev.. 6(1), 25-59.

Larcom, S. 2015. Natural Resource Contests in Papua New Guinea: Causes and Consequences. Mimeo

Logan,C. 2013. The roots of resilience: Exploring popular support for African traditional authorities. Afr. Aff., 112(448), 353-376.

Mamdani, M. 1996. Citizen and subject. Princeton: Princeton University Press.

Mayaux, P., J. Pekel, B. Desclée, F. Donnay, A. Lupi, F. Achard, M. Clerici et al. 2013.State and evolution of the African rainforests between 1990 and 2010. Phil. Trans. of the R. Soc. $B, 368(1625), 1-10$.

Michalopoulos, S. 2012 The origins of ethnolinguistic diversity. The Am. Econ. Rev. 102(4), 1508-1539.

Michalopoulos, S., and E. Papaioannou. 2013. Precolonial ethnic institutions and contemporary African Dev. Econometrica, 81(1), 113-152.

Michalopoulos, S., and E. Papaioannou. 2014. National Institutions and Subnational Development in Africa. The Quart. J. of Econ., 129(1), 151-213.

Meinzen-Dick, R. S., and R. Pradhan. 2001. Implications of legal pluralism for natural resource management. IDS Bull., 32(4), 10-17.

Murdock, G. P. 1967. Ethnographic atlas: a summary. Ethnology, 6(2), 109-236. 
Nordhaus, W. 1975. The political business cycle. The Rev. of Econ. Stud., 42(2), 169-190.

Nunn, N. and L. Wantchekon (2011): The Slave Trade and the Origins of Mistrust in Africa, Am. Econ. Rev., 101 (7), 3221-3252.

Olson, D.M., E. Dinerstein, E.D. Wikramanayake, N.D. Burgess, G.V.N. Powell, E.C. Underwood, J.A. D'Amico, I. Itoua, H.E. Strand, J.C. Morrison, C.J. Loucks, T.F. Allnutt, T.H. Ricketts, Y. Kura, J.F. Lamoreux, W.W. Wettengel, P. Hedao, and K.R. Kassem. Terrestrial Ecoregions of the World: A New Map of Life on Earth.

BioSci., 51, 933-938.

Osei-Tutu, P, M. Pregernig, and B. Pokorny. 2014. Legitimacy of informal institutions in contemporary local forest management: insights from Ghana. Biodiv. and Conserv. 23(14), 3587-3605.

Otsuka, K., and F. M. Place. 2001. Land tenure and natural resource management: A comparative study of agrarian communities in Asia and Africa. International Food Policy Research Institute: Washington D.C.

Pfaff, A., Robalino, J., Lima, E., Sandoval, C., \& Herrera, L. D. 2014. Governance, location and avoided deforestation from protected areas: greater restrictions can have lower impact, due to differences in location. World Dev., 55, 7-20.

IUCN and UNEP-WCMC (2013), The World Database on Protected Areas (WDPA), Cambridge, UK: UNEP-WCMC. Available at: www.protectedplanet.net. Accessed May 2014.

Ramsar 2013. Ramsar Sites Information Service. Available from: http://ramsar.wetlands.org/ Accessed May 2014. 
Richards, P. 1998. Fighting for the rain forest: war, youth \& resources in Sierra Leone (No. Reprinted Ed.). James Currey Ltd.

Thondhlana, Gladman, Sheona Shackleton, and James Blignaut. 2015. Local institutions, actors, and natural resource governance in Kgalagadi Transfrontier Park and surrounds, South Africa. Land Use Policy 47, 121-129.

United Nations. 2013. The Millennium Development Goals Report 2013, United Nations: New York.Available at: http://www.un.org/millenniumgoals/reports.shtml. Accessed February 2014.

World Bank. 2013. World Development Indicators. World Bank: Washington D.C.

Ziltener, P., and H-P, Mueller. 2007. The weight of the past traditional agriculture, sociopolitical differentiation and modern Dev. in Africa and Asia: a cross-national analysis. Inter. J. of Comp. Sociol., 48(5), 371-415.

Ziltener, P., and D. Künzler. 2013. Impacts of Colonialism: A Research Survey. J. of World Syst. Res. 19(2), 290-311. Data available at:

http://www.worldDev..uzh.ch/research/impa/polim.html. Accessed June 2014. 


\section{APPENDIX}

\begin{tabular}{|c|c|c|c|}
\hline Variable & Description & $\begin{array}{l}\text { Level of } \\
\text { Aggregation }\end{array}$ & Source \\
\hline $\begin{array}{l}\text { Measure of } \\
\text { deforestation } \\
\text { (g_net) }\end{array}$ & $\begin{array}{l}\text { The percentage of the precolonial society area that } \\
\text { underwent net forest loss between 2000-2012. Net } \\
\text { forest loss is the difference between loss and gain of } \\
\text { forest cover. }\end{array}$ & Precolonial society & Hansen et al. (2013) \\
\hline $\begin{array}{l}\text { Forest area in } \\
2000 \\
\text { (g_treecov_200 } \\
0 \text { ) }\end{array}$ & $\begin{array}{l}\text { The mean tree cover in } 2000 \text { within the boundaries } \\
\text { of each precolonial society, measured in the range } 0 \text { - } \\
100 \text {. }\end{array}$ & Precolonial society & Hansen et al. (2013) \\
\hline $\begin{array}{l}\text { Forest area in } \\
2003 \\
\text { (tc_forest2003) }\end{array}$ & $\begin{array}{l}\text { The percentage of forested land in } 2003 \text { within the } \\
\text { boundaries of each precolonial society. Forested land } \\
\text { is defined as land where the tree cover is at least } 30 \\
\text { per cent. }\end{array}$ & Precolonial society & $\begin{array}{l}\text { Calculated using raster } \\
\text { data based on MODIS } \\
\text { images for the year } \\
\text { 2003; Available from } \\
\text { http://www.iscgm.org/ }\end{array}$ \\
\hline $\begin{array}{l}\text { Forest area in } \\
2008 \\
\text { (tc_forest2008) }\end{array}$ & $\begin{array}{l}\text { The percentage of forested land in } 2008 \text { within the } \\
\text { boundaries of each precolonial society. Forested land } \\
\text { is defined as land where the tree cover is at least } 30 \\
\text { per cent. }\end{array}$ & Precolonial society & $\begin{array}{l}\text { Calculated using raster } \\
\text { data based on MODIS } \\
\text { images for the year } \\
\text { 2008; Available from } \\
\text { http://www.iscgm.org/ }\end{array}$ \\
\hline $\begin{array}{l}\text { Alternative } \\
\text { measure for } \\
\text { Deforestation } \\
\text { (tc_forestdiff) }\end{array}$ & $\begin{array}{l}\text { The fractional change in forested land within the } \\
\text { boundaries of each precolonial society between } 2003 \\
\text { and } 2008 \text {. }\end{array}$ & Precolonial society & $\begin{array}{l}\text { Calculated using raster } \\
\text { data based on MODIS } \\
\text { images for the years } \\
2003 \text { and } 2008 ; \\
\text { Available from } \\
\text { http://www.iscgm.org/ }\end{array}$ \\
\hline Rule of law & $\begin{array}{l}\text { A composite variable that captures perceptions of the } \\
\text { extent to which agents have confidence in and abide } \\
\text { by the rules of society, and in particular the quality } \\
\text { of contract enforcement, property rights, the police, } \\
\text { and the courts, as well as the likelihood of crime and } \\
\text { violence. }\end{array}$ & Country & $\begin{array}{l}\text { Available at } \\
\text { http://info.worldbank.or } \\
\text { g/governance/wgi/inde } \\
\text { x.aspx }\end{array}$ \\
\hline Protected areas & $\begin{array}{l}\text { The percentage of the precolonial society area which } \\
\text { was declared as protected on or prior to } 2003 \text {. }\end{array}$ & Precolonial society & $\begin{array}{l}\text { Available from } \\
\text { www.protectedplanet.n } \\
\text { et and } \\
\text { http://ramsar.wetlands. } \\
\text { org/ }\end{array}$ \\
\hline $\begin{array}{l}\text { Colonial } \\
\text { Duration }\end{array}$ & The duration of colonization in years. & Country & $\begin{array}{l}\text { Ziltener and Kuenzler } \\
\text { (2013) }\end{array}$ \\
\hline Indirect Control & $\begin{array}{l}\text { A measure of different levels of political domination, } \\
\text { where } 0 \text { represents direct control and } 1 \text { represents } \\
\text { indirect control. }\end{array}$ & Country & $\begin{array}{l}\text { Based on Ziltener and } \\
\text { Kuenzler (2013) }\end{array}$ \\
\hline $\begin{array}{l}\text { Colonial } \\
\text { Intensity }\end{array}$ & $\begin{array}{l}\text { A measure of the intensity of colonization. } \\
\text { Calculated as the sum of the logarithms of colonial } \\
\text { duration and indirect control. }\end{array}$ & Country & $\begin{array}{l}\text { Calculated using data } \\
\text { from Ziltener and } \\
\text { Kuenzler (2013). }\end{array}$ \\
\hline Legal origin & A binary variable where a value of 0 represents & Country & Available from \\
\hline
\end{tabular}


British legal origin and a value of 1 represents French legal origin. Political
centralization
$\begin{aligned} & \text { Succession of } \\ & \text { chiefs }\end{aligned}$

Population density

Distance from closest sea

Distance from national border

Distance from capital city

Latitude

Longitude

Land suitability for agriculture

Elevation

Malaria stability index

Light density
A binary variable where a value of 0 represents a fragmented society and a value of 1 represents a centralized society

A categorical variable where a value of 0 represents a precolonial society where succession of chiefs is hereditary; a value of 1 represents democratic election; a value of 2 represents election from above; and a value of 3 represents election by social standing.

Population density per square kilometer in 2000 $(\log )$.

The geodesic distance (in 1,000km) from the centroid of each precolonial society to the nearest coastline.

The geodesic distance (in 1,000km) from the centroid of each precolonial society to the nearest border.

The geodesic distance (in $1,000 \mathrm{~km}$ ) from the centroid of each precolonial society to the capital city of the current country .

The geographical latitude of a precolonial state.

The geographical longitude of a precolonial state.

The average value of an index consisting of the climatic and soil suitability for agriculture.

Average elevation (in kilometres).

The average value of an index taking into account types of mosquiotoes indigenous to a region and their prevalence.

The average luminosity across pixels in 2007 and $2008(\log )$.
Precolonial society

Precolonial society 
Table S2: Partial correlation of control variables

\begin{tabular}{lr}
\hline Variable & Partial correlation \\
\hline Population density $(\log )$ & -0.128 \\
Distance from closest sea & 0.092 \\
Distance from national border & -0.039 \\
Distance from capital city & -0.075 \\
Latitude & 0.123 \\
Longitude & 0.118 \\
Land suitability for agriculture & -0.039 \\
Elevation & 0.053 \\
Malaria stability index & -0.058 \\
Light density (log) & 0.062 \\
Protected areas & -0.014 \\
Forest area in 2000 & -0.312 \\
\hline
\end{tabular}

Table S3: Correlation matrix of key variables

\begin{tabular}{lrrrr}
\hline & $\begin{array}{c}\text { Deforestation } \\
\left(\boldsymbol{g} \_n e t\right)\end{array}$ & $\begin{array}{c}\text { Light density } \\
(\mathbf{l o g})\end{array}$ & $\begin{array}{c}\text { Protected } \\
\text { areas }\end{array}$ & $\begin{array}{c}\text { Forest area in } \\
\mathbf{2 0 0 0}\end{array}$ \\
\hline Deforestation $\left(g \_n e t\right)$ & 1.000 & & & \\
Light density $(\log )$ & 0.010 & 1.000 & & \\
Protected areas & -0.049 & -0.014 & 1.000 & 1.000 \\
Forest area in 2000 & -0.409 & -0.138 & 0.092 & \\
\hline
\end{tabular}


Table S4: Summary statistics of control variables

\begin{tabular}{lccccc}
\hline \multicolumn{1}{c}{ Variable } & $\boldsymbol{N}$ & Mean & Std. Dev. & \multicolumn{1}{c}{ Min } & Max \\
\hline Population density (log) & 683 & 2.899 & 2.022 & -4.605 & 7.432 \\
Distance from closest sea & 683 & 0.589 & 0.421 & 0.001 & 1.704 \\
Distance from national border & 683 & 0.102 & 0.111 & 0.001 & 0.617 \\
Distance from capital city & 683 & 0.504 & 0.387 & 0.011 & 1.882 \\
Latitude & 683 & 4.537 & 12.066 & -32 & 37 \\
Longitude & 683 & 16.347 & 16.638 & -32 & 48 \\
Land suitability for agriculture & 683 & 0.435 & 0.241 & 0.001 & 0.979 \\
Elevation & 683 & 0.634 & 0.467 & 0 & 2.181 \\
Malaria stability index & 683 & 0.724 & 0.329 & 0 & 1 \\
Light density (log) & 683 & -2.946 & 1.701 & -4.605 & 3.225 \\
Forest area in 2000 & 683 & 25.312 & 26.430 & 0 & 99.229 \\
Forest area in 2003 & 683 & 37.412 & 37.404 & 0 & 98.58 \\
\hline
\end{tabular}

